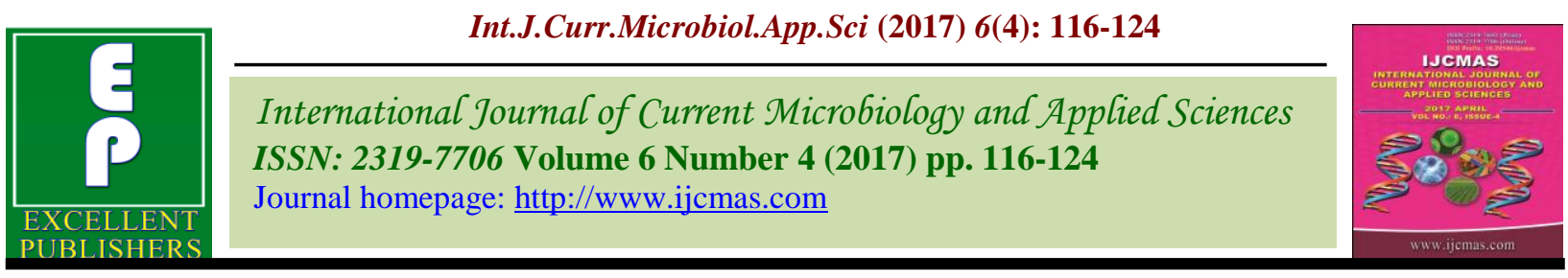

Original Research Article

https://doi.org/10.20546/ijcmas.2017.604.014

\title{
Physiological and Biochemical Evaluation of Fomesafen Toxicity in Female Albino Wistar Rats
}

\author{
Alok Paliwal', M.L. Agarwal', K.M. Chacko', Anurag Singh², \\ Abhishek Chauhan ${ }^{3}$ and Tanu Jindal ${ }^{3 *}$ \\ ${ }^{1}$ Shriram Institute for Industrial Research, 19-University Road, Delhi-110007, India \\ ${ }^{2}$ EM Facility, Department of Anatomy, AIIMS, Delhi-110029, India \\ ${ }^{3}$ Amity Institute of Environmental Toxicology, Safety and Management, Amity University, \\ Sector-125, Noida, Uttar Pradesh, India \\ *Corresponding author
}

\begin{tabular}{|c|c|}
\hline & B S T R A C T \\
\hline $\begin{array}{l}\text { Herbicides, } \\
\text { Fomesafen, Wistar } \\
\text { rat, Blood } \\
\text { biochemistry, } \\
\text { Repeated exposure. }\end{array}$ & \multirow{3}{*}{$\begin{array}{l}\text { Fomesafen is widely used as herbicide for weed control. Fomesafen have both foliar and } \\
\text { soil activity. It mostly control broadleaves. Fomesafen is labeled for postemergence } \\
\text { applications to soybeans, peanuts, and rice. Although bronzing or burning of soybean leaf } \\
\text { tissue is evident after application, yield is rarely affected. The present study was designed } \\
\text { to evaluate the effect of repeated exposure of Fomesafen (Herbicide) by oral gavage } \\
\text { method on the blood biochemistry of female wistar rats. The study highlights the various } \\
\text { changes in biochemical parameters of female wistar rats over repeated exposure by } \\
\text { Fomesafen by oral route through gavage. Under the conditions of this study, the repeated } \\
\text { oral administration of 'Fomesafen technical' in Female wistar rats at the dosage level of } 50 \\
\text { mg/kg b.wt. for consecutive } 90 \text { days did not induce any observable toxic effects, alteration } \\
\text { in blood biochemistry parameters when compared to its corresponding control group of } \\
\text { animals. }\end{array}$} \\
\hline Article Info & \\
\hline $\begin{array}{l}\text { Accepted: } \\
\text { 02 March } 2017 \\
\text { Available Online: } \\
10 \text { April } 2017\end{array}$ & \\
\hline
\end{tabular}

\section{Introduction}

The use of herbicides is increasing in worldwide crop production. The value of the worldwide herbicide market grew by $39 \%$ between 2002 and 2011 and is projected to grow by another $11 \%$ by 2016 (Philips McDougall, 2013). Herbicides are being rapidly adopted in developing countries that face shortages of hand weeding labor and the need to raise crop yields (Zhang, 2003). Improved weed control with herbicides has the potential greatly to improve crop yields in many developing countries in the near future (Masthan et al., 1989). Increased herbicide use promotes fertilizer use, which leads to even greater yield increases (Manda, 2011).
Research has shown that, if enough hand weeding is done at the optimal times, crop yields are not reduced by weed competition (Prasad et al., 2008). In reality, crop fields are seldom adequately weeded by hand; weeding is tedious and time consuming. Laborers are not always available when needed (De Datta and Barker, 1997). Weeding is often done late, causing drastic losses in yield (Rashid et $a l ., 2012)$. The use of herbicides has gained impetus from the general rise in farm wages as a consequence of overall economic growth and growth in non-farm employment opportunities, particularly in Asia adequate non-chemical controls for weeds are not 
available, and herbicide use is increasing dramatically as a result of rising opportunity costs of labor across the developing world (Pingali and Gerpacio, 1997). Herbicide use is increasing in many countries where tillage and flooding for weed control are being reduced in order to conserve natural resources: soil, water and energy.

Selective herbicides kill certain targets while leaving the desired crop relatively unharmed. Some of these act by interfering with the growth of the weed and are often based on plant hormones. Herbicides used to clear waste ground are nonselective and kill all plant material with which they come into contact. Some plants produce natural herbicides, such as the genus Juglans (walnuts). Herbicides are widely used in agriculture and in landscape turf management. They are applied in total vegetation control (TVC) programs for maintenance of highways and railroads. Smaller quantities are used in forestry, pasture systems, and management of areas set aside as wildlife habitat. Herbicides have been alleged to cause a variety of health effects ranging from skin rashes to death. The pathway of attack can arise from improper application resulting in direct contact with field workers, inhalation of aerial sprays, food consumption and from contact with residual soil contamination. Herbicides can also be transported via surface runoff to contaminate distant surface waters and hence another pathway of ingestion through extraction of those surface waters for drinking. Some herbicides decompose rapidly in soils and other types have more persistent characteristics with longer environmental half-lives. In Asia, particularly in the Philippines; the proportion of rice farmers using herbicides increased from 14\% in 1966 to $61 \%$ in 1974 (De Datta and Barker, 1997). Today, 96-98\% of Philippine rice farmers use herbicides (Marsh, 2009). A recent study determined that, with increased labor cost, herbicide application in rice fields is superior to manual weeding even at the lowest weed density by \$US 25-54 ha. At the highest weed density and highest labor cost, herbicide application is approximately $80 \%$ (about \$US 200 per ha) more profitable than hand weeding (Beltran et al., 2012). In Bangladesh, the loss in rice yield in farmers' fields as a result of poor weeds control has been determined to be $43-51 \%$ (Rashid et al., 2012). The yield gap between herbicide use and hand weeding is as high as 1 metric $\mathrm{t} \mathrm{ha}^{-1}$, with $30 \%$ of farmers losing in excess of 500 $\mathrm{kg} \mathrm{ha}^{-1}$ in the absence of herbicides

Trends of herbicide consumption in the world and its expenditure Annual usage of herbicides in the world was about 4000 million pounds in the 1953 's, increasing to nearly 121000 million pounds at the end of 2013 (WAP, 2014). Since then, at the end of each five years $15-24 \%$ increment occurred (Fig. 3). The herbicide industry is quite significant in dollar terms. Annual expenditures by users of herbicide totaled about \$US33 billion in 1953 and \$US 998 at the end of 2013 (Fig. 4). It is clear from the figure that, there is a sharp increasing trend in consuming herbicides which triggers to increase the market expenditure for herbicides. In future, by the end of 2025, it is supposed the herbicides consumption to be increased by 150000 million pounds which will costs around \$US 2000. The present study was designed by dividing the 60 female wistar rats into six groups (G1 - G6), blood collection was done under light anesthesia $\left(\mathrm{CO}_{2}\right)$ through retro orbital sinuses and different biochemical parameter like Glucose (mg/dl), Serum Glutamate Oxaloacetate Transferase (U/L), Serum Glutamate Pyruvate Transferase (U/L), Blood Urea Nitrogen (mg/dl), Serum Alkaline Phosphatase (U/L), Total Protein (g/dl), Sodium (mEq/L), Potassium $(\mathrm{mEq} / \mathrm{L})$, Cholride $(\mathrm{mEq} / \mathrm{L})$ and Cholinesterase (U/L) were studied using Beckman Coulter AU480 Clinical Chemistry autoanalyser system. 


\section{Methods and Materials}

\section{Animal selection}

The Female Wistar Rat of age 5-8 weeks and body weight in the range 100-140 gm of was selected for use in this study due to availability of comprehensive background data relating to pathological and clinical parameters, at this laboratory; widely used as a species to predict toxicity of the test item in human and larger animals.

\section{Animal identification and acclimatization}

Animal identification was done with the help of marking ink. Each cage was tagged with appropriate label mentioning the description of study number, study name, dose level, group name, animal number, sex of the animal, date of initiation of experiment, date of dosing and date of completion of the experiment. Acclimatization of the animal was done before initiation of dosing during experiment period the animals were housed in animal house and the husbandry done under good environmental Conditions.

\section{Environmental conditions and maintenance of animals}

The experimental room was monitored for temperature, humidity, light intensity and air changes. The room temperature was maintained at $22 \pm 3^{\circ} \mathrm{C}$ with $50-60 \%$ relative humidity. The room was ventilated at the rate of approximately 15 air changes per hour and lighting was controlled to give 12 hours artificial light (8 a.m-8 p.m) each day. Whereas; housing of animals is done randomly selected animals were caged in a group of 5 according to sex in polypropylene rat cages fitted with wire mesh tops and having autoclaved clean corn Cobb bedding. A sample of bedding material was analyzed for microbiological and chemical contaminants on a routine basis (Chauhan et al., 2015). There were no known contaminants in the bedding material. Animals were feed with Sterilized standard pellet feed (Amrut Feeds Ltd.) and available ad libitum to the experimental animals. The quality of feed was regularly monitored at the NABL accredited laboratory of Shriram Institute for Industrial Research. There were no known contaminants in the feed at levels that would have potential to influence the outcome of this study. Drinking Filtered drinking water was available ad libitum to the experimental animals through polypropylene bottles fitted with nozzles. The quality of water was regularly monitored at the NABL accredited laboratory of Shriram Institute for Industrial Research. There were no known contaminants in the water at levels that would have potential to influence the outcome of this study.

\section{Animal welfare}

All animals were handled with similar due regard for their welfare and the conditions in accordance to the standard operating procedures in compliance with the regulations of the Committee for the Purpose of Control and Supervision of Experiments on Animals (CPCSEA), Govt. of India. Room sanitation was done on routine basis, the floor, work tops of the experimental room was swept and mopped with a disinfectant solution (D 125/D-256).

\section{Acute oral toxicity study}

In the assessment and evaluation the toxic characteristic of a test item, determination of 'Acute oral toxicity in wistar rats' is usually a stepwise procedure. This study was hence, performed to assess the acute oral toxicity of 'Fomesafen Technical' in wistar rat, A study at the dose of $2000 \mathrm{mg} / \mathrm{kg}$ B.wt. was conducted, taking 3 females rats (nulliparous and non pregnant) as per the recommendation of the guideline (OECD No.423). A single 
oral gavage dose was administered to the animals with the help of cannula attached to a syringe. The animals were fasted overnight prior to dosing.

\section{Repeated oral exposure study}

A total of 60 females were selected and randomly distributed into six groups with 10 animals /group. At the commencement of the study, the weight variation of animals used, was minimal and did not exceed $\pm 20 \%$ of the mean weight of each group. Four groups of 10 female rats were administered with test item 'Fomesafen technical' at the dose levels of 0 , 50,100 and $250 \mathrm{mg} / \mathrm{kg}$ B.wt and two additional recovery groups of 10 female each at the dose level of $0,100 \mathrm{mg} / \mathrm{kg} \mathrm{B}$.wt. were administered with test item 'Fomesafen technical' by oral route over a period for 90 days. The blood collection of rats was done by deeply anesthetized by exposure to $\mathrm{CO}_{2}$. The depth of anesthesia was assured by the constriction of the pupils as well as simple sensory tests, such as the absence of eye blinking when the eyelid was touched and the absence of foot withdrawal when the foot was pinched. Blood was collected by orbital sinuses for interim evaluation of blood biochemistry parameter and for terminal sacrifice the thoracic cavity was opened. Whole blood was collected in EDTA vacutainer tubes via abdominal aorta The biochemical parameters e.g. Glucose (mg/dl), Serum Glutamate Oxaloacetate Transferase (U/L), Serum Glutamate Pyruvate Transferase (U/L), Blood Urea Nitrogen (mg/dl), Serum Alkaline Phosphatase (U/L), Total Protein $(\mathrm{g} / \mathrm{dl})$, Sodium $(\mathrm{mEq} / \mathrm{L})$, Potassium $(\mathrm{mEq} / \mathrm{L})$, Cholride $(\mathrm{mEq} / \mathrm{L})$ and Cholinesterase (U/L) were studied using Beckman Coulter AU480 Clinical Chemistry autoanalyser system.

\section{Dose preparation}

Different doses were prepared in corn oil in calibrated volumetric flasks at the dose levels of $50 \mathrm{mg} / \mathrm{kg} \mathrm{b.wt,} 100 \mathrm{mg} / \mathrm{kg}$ b.wt. and 250 $\mathrm{mg} / \mathrm{kg} \mathrm{b}$.wt. for low, intermediate and high dose groups respectively and $100 \mathrm{mg} / \mathrm{kg} \mathrm{b.wt}$. for recovery intermediate dose group. Doses were prepared freshly prior to dosing. Administration of dose was done $10 \mathrm{ml} / \mathrm{kg}$ body weight was maintained for each rat. All rats were dosed by gavage using a cannula attached to a syringe.

\section{Statistical analysis}

All the Statistical analysis were done using MiniTab 16.0. Standard errors and one way ANOVA were calculated for given data

\section{Results and Discussion}

The Acute study was performed before the initiation of main study i.e. repeated exposure study with Fomesafen on female wistar rats. In Acute study the expose animal via oral route showed No treatment related toxic signs and symptoms or mortality in any of the animal at the dose level of $2000 \mathrm{mg} / \mathrm{kg}$ B.wt. Under the conditions of this study, no toxic sign and symptoms/mortality was observed in any of the animals at the maximum dose level of $2000 \mathrm{mg} / \mathrm{kg}$ B.wt. Hence, the LD50 range of 'Fomesafen Technical' lies between $>2000-5000 \mathrm{mg} / \mathrm{kg} \mathrm{B.wt}$. and is categorized as $2000 \mathrm{mg} / \mathrm{kg}<\mathrm{LD} 50<5000 \mathrm{mg} / \mathrm{kg}$ (Category 5) as per the Globally Harmonized Classification System (GHS). Based on the observation of acute study a main study was designed with 60 females wistar rats and grouped into six group (G1 - G6) Four groups of 10 female rats were administered with test item 'Fomesafen technical' at the dose levels of $0,50,100$ and $250 \mathrm{mg} / \mathrm{kg}$ B.wt and two additional recovery groups of 10 female each at the dose level of $0,100 \mathrm{mg} / \mathrm{kg}$ B.wt. were administered with test item 'Fomesafen technical' by oral route over a period for 90 days. 
Table.1 Experimental design

\begin{tabular}{|l|c|c|c|c|}
\hline \multicolumn{1}{|c|}{ Group } & $\begin{array}{c}\text { Dosage Level } \\
(\mathrm{mg} / \mathrm{kg} \text { B.wt.) }\end{array}$ & $\begin{array}{c}\text { Animals } \\
\text { used }\end{array}$ & $\begin{array}{c}\text { Terminal Sacrifice } \\
\text { (Sacrificed after 90 days } \\
\text { dose administration) }\end{array}$ & $\begin{array}{c}\text { Post Terminal } \\
\text { Sacrifice (Sacrificed after 28 } \\
\text { days post treatment) }\end{array}$ \\
\hline Control (vehicle only) G-1 & 0 & 10 & 10 & - \\
\hline Low dose G-2 & 50 & 10 & 10 & - \\
\hline Intermediate dose G-3 & 100 & 10 & 10 & - \\
\hline High dose G-4 & 250 & 10 & 10 & - \\
\hline Recovery Control G-5 & 0 & 10 & 0 & 10 \\
\hline Recovery Intermediate Dose G-6 & 100 & 10 & 0 & 10 \\
\hline
\end{tabular}

Table.2 Mean biochemistry data of female rats time: pretest (0th Day)

\begin{tabular}{|c|c|c|c|c|c|c|c|c|c|c|c|}
\hline Groups & $\begin{array}{c}G L U \\
(m g / d l)\end{array}$ & $\begin{array}{l}S G O T \\
(U / L)\end{array}$ & $\begin{array}{l}S G P T \\
(U / L)\end{array}$ & $\begin{array}{c}\text { BUN } \\
(\mathrm{mg} / \mathrm{dl})\end{array}$ & $\begin{array}{r}\text { UREA } \\
\text { (mg/dl) }\end{array}$ & $\begin{array}{c}\text { SAP } \\
(\mathbf{U} / \mathbf{L})\end{array}$ & $\underset{(\mathrm{g} / \mathrm{dl})}{\mathbf{T P}}$ & $\begin{array}{c}\text { Sodium } \\
(\mathrm{mEq} / \mathrm{L})\end{array}$ & $\begin{array}{c}\text { Potassium } \\
(m E q / L)\end{array}$ & $\begin{array}{l}\text { Chloride } \\
(\mathrm{mEq} / \mathrm{L})\end{array}$ & $\begin{array}{c}\text { cholineste } \\
\text { rase } \\
\text { (U/L) }\end{array}$ \\
\hline $\begin{array}{c}\text { Control } \\
\text { (G-1) }\end{array}$ & $\begin{array}{c}99.72 \\
\pm \\
0.95 \\
\end{array}$ & $\begin{array}{c}85.87 \\
\pm \\
2.97 \\
\end{array}$ & $\begin{array}{c}47.16 \\
\pm \\
3.54\end{array}$ & $\begin{array}{c}18.04 \\
\pm \\
0.53 \\
\end{array}$ & $\begin{array}{c}37.60 \\
\pm \\
1.32 \\
\end{array}$ & $\begin{array}{c}117.63 \\
\pm \\
5.02\end{array}$ & $\begin{array}{c}6.94 \\
\pm \\
0.50\end{array}$ & $\begin{array}{c}140.80 \\
\pm \\
2.10\end{array}$ & $\begin{array}{c}4.69 \\
\pm \\
0.50\end{array}$ & $\begin{array}{c}98.90 \\
\pm \\
0.88\end{array}$ & $\begin{array}{c}652.40 \\
\pm \\
4.30\end{array}$ \\
\hline $\begin{array}{c}\text { Low Dose } \\
\quad(\mathbf{G}-2)\end{array}$ & $\begin{array}{c}100.47 \\
\pm \\
1.10\end{array}$ & $\begin{array}{c}87.11 \\
\pm \\
3.06\end{array}$ & $\begin{array}{c}46.53 \\
\pm \\
4.67\end{array}$ & $\begin{array}{c}18.04 \\
\pm \\
0.43\end{array}$ & $\begin{array}{c}38.54 \\
\pm \\
0.81\end{array}$ & $\begin{array}{c}117.36 \\
\pm \\
7.05\end{array}$ & $\begin{array}{c}6.91 \\
\pm \\
0.42\end{array}$ & $\begin{array}{c}140.60 \\
\pm \\
1.51\end{array}$ & $\begin{array}{c}4.82 \\
\pm \\
0.42\end{array}$ & $\begin{array}{c}99.00 \\
\pm \\
0.82\end{array}$ & $\begin{array}{c}653.30 \\
\pm \\
4.99\end{array}$ \\
\hline $\begin{array}{c}\text { Intermediate } \\
\text { Dose } \\
(\mathbf{G - 3})\end{array}$ & $\begin{array}{c}99.92 \\
\pm \\
2.44\end{array}$ & $\begin{array}{c}85.73 \\
\pm \\
4.09\end{array}$ & $\begin{array}{c}46.48 \\
\pm \\
3.51\end{array}$ & $\begin{array}{c}18.15 \\
\pm \\
0.66\end{array}$ & $\begin{array}{c}38.40 \\
\pm \\
1.01\end{array}$ & $\begin{array}{c}116.22 \\
\pm \\
3.29\end{array}$ & $\begin{array}{c}6.59 \\
\pm \\
0.28\end{array}$ & $\begin{array}{c}139.40 \\
\pm \\
1.96\end{array}$ & $\begin{array}{c}5.12 \\
\pm \\
0.32\end{array}$ & $\begin{array}{c}99.60 \\
\pm \\
1.07\end{array}$ & $\begin{array}{c}652.10 \\
\pm \\
4.86\end{array}$ \\
\hline $\begin{array}{l}\text { High Dose } \\
\quad(G-4)\end{array}$ & $\begin{array}{c}100.10 \\
\pm \\
1.12\end{array}$ & $\begin{array}{c}86.68 \\
\pm \\
6.56\end{array}$ & $\begin{array}{c}47.71 \\
\pm \\
2.83\end{array}$ & $\begin{array}{c}18.62 \\
\pm \\
0.43\end{array}$ & $\begin{array}{c}38.94 \\
\pm \\
1.14\end{array}$ & $\begin{array}{c}116.08 \\
\pm \\
4.18\end{array}$ & $\begin{array}{c}7.41 \\
\pm \\
0.41\end{array}$ & $\begin{array}{c}140.82 \\
\pm \\
1.40\end{array}$ & $\begin{array}{c}4.71 \\
\pm \\
0.37\end{array}$ & $\begin{array}{c}99.77 \\
\pm \\
1.70\end{array}$ & $\begin{array}{c}654.30 \\
\pm \\
5.77\end{array}$ \\
\hline $\begin{array}{c}\text { Recovery control } \\
(\mathbf{G - 5})\end{array}$ & $\begin{array}{c}100.17 \\
\pm \\
0.86\end{array}$ & $\begin{array}{c}87.48 \\
\pm \\
2.72 \\
\end{array}$ & $\begin{array}{c}48.26 \\
\pm \\
2.58 \\
\end{array}$ & $\begin{array}{c}18.35 \\
\pm \\
0.51 \\
\end{array}$ & $\begin{array}{c}38.66 \\
\pm \\
1.03 \\
\end{array}$ & $\begin{array}{c}116.21 \\
\pm \\
3.74\end{array}$ & $\begin{array}{c}7.15 \\
\pm \\
0.52 \\
\end{array}$ & $\begin{array}{c}140.51 \\
\pm \\
1.44 \\
\end{array}$ & $\begin{array}{c}4.55 \\
\pm \\
0.32 \\
\end{array}$ & $\begin{array}{c}99.66 \\
\pm \\
1.63 \\
\end{array}$ & $\begin{array}{c}654.90 \\
\pm \\
3.73\end{array}$ \\
\hline $\begin{array}{c}\text { Recovery } \\
\text { Intermediate } \\
\text { dose (G-6) }\end{array}$ & $\begin{array}{c}100.10 \\
\pm \\
1.12\end{array}$ & $\begin{array}{c}87.16 \\
\pm \\
2.48\end{array}$ & $\begin{array}{c}46.33 \\
\pm \\
2.15\end{array}$ & $\begin{array}{c}18.33 \\
\pm \\
0.46\end{array}$ & $\begin{array}{c}38.32 \\
\pm \\
1.18\end{array}$ & $\begin{array}{c}115.71 \\
\pm \\
2.66\end{array}$ & $\begin{array}{c}6.95 \\
\pm \\
0.53\end{array}$ & $\begin{array}{c}140.50 \\
\pm \\
1.18\end{array}$ & $\begin{array}{c}4.59 \\
\pm \\
0.23\end{array}$ & $\begin{array}{c}99.60 \\
\pm \\
1.17\end{array}$ & $\begin{array}{c}652.10 \\
\pm \\
3.96\end{array}$ \\
\hline
\end{tabular}

Statistical analysis: ANOVA (p value:> 0.05) 
Table.3 Mean biochemistry data of female rats

\begin{tabular}{|c|c|c|c|c|c|c|c|c|}
\hline \multirow[t]{2}{*}{ Parameters } & \multicolumn{2}{|c|}{$\begin{array}{c}\text { Control } \\
\text { (G-1) }\end{array}$} & \multicolumn{2}{|c|}{$\begin{array}{c}\text { Low Dose } \\
(\text { G-2) }\end{array}$} & \multicolumn{2}{|c|}{$\begin{array}{c}\text { Intermediate Dose } \\
(\mathbf{G - 3})\end{array}$} & \multicolumn{2}{|c|}{$\begin{array}{c}\text { High Dose } \\
(G-4)\end{array}$} \\
\hline & Day $45^{\text {th }}$ & Day $91^{\text {st }}$ & Day $45^{\text {th }}$ & Day $91^{\text {st }}$ & Day $45^{\text {th }}$ & Day $91^{\text {st }}$ & Day $45^{\text {th }}$ & Day $91^{\text {st }}$ \\
\hline GLU (mg/dl) & $77.30 \pm 2.67$ & $80.90 \pm 5.26$ & $81.70 \pm 5.72$ & $81.00 \pm 6.67$ & $84.60 \pm 4.48$ & $78.00 \pm 4.85$ & $79.40 \pm 7.18$ & $81.10 \pm 5.17$ \\
\hline SGOT (U/L) & $82.70 \pm 3.50$ & $87.10 \pm 4.48$ & $84.50 \pm 4.74$ & $80.60 \pm 4.33$ & $85.60 \pm 3.10$ & $87.10 \pm 6.26$ & $83.40 \pm 4.72$ & $85.90 \pm 9.83$ \\
\hline SGPT (U/L) & $41.50 \pm 2.68$ & $46.60 \pm 1.58$ & $43.60 \pm 3.69$ & $42.00 \pm 3.40$ & $45.40 \pm 3.47$ & $52.02 \pm 13.53$ & $42.60 \pm 5.13$ & $54.00 \pm 15.07$ \\
\hline BUN (mg/dl) & $19.63 \pm 1.41$ & $21.31 \pm 1.50$ & $21.82 \pm 0.88$ & $20.09 \pm 1.57$ & $20.93 \pm 1.24$ & $20.75 \pm 1.47$ & $20.56 \pm 1.39$ & $20.37 \pm 1.31$ \\
\hline UREA (mg/dl) & $42.00 \pm 3.02$ & $45.60 \pm 3.20$ & $46.70 \pm 1.89$ & $43.00 \pm 3.37$ & $44.80 \pm 2.66$ & $44.40 \pm 3.13$ & $44.00 \pm 2.98$ & $43.60 \pm 2.80$ \\
\hline SAP (U/L) & $103.50 \pm 4.74$ & $101.50 \pm 6.08$ & $105.20 \pm 6.18$ & $104.70 \pm 8.64$ & $107.40 \pm 4.97$ & $109.90 \pm 10.63$ & $105.00 \pm 6.62$ & $105.10 \pm 7.81$ \\
\hline T.P (g/dl) & $7.48 \pm 0.37$ & $7.88 \pm 0.21$ & $8.09 \pm 0.23$ & $7.62 \pm 0.29$ & $7.92 \pm 0.24$ & $7.81 \pm 0.21$ & $7.84 \pm 0.17$ & $7.82 \pm 0.19$ \\
\hline $\mathrm{Na}^{+}(\mathbf{m E q} / \mathbf{L})$ & $143.90 \pm 2.77$ & $144.40 \pm 2.27$ & $144.70 \pm 1.49$ & $142.80 \pm 2.44$ & $144.70 \pm 1.89$ & $143.40 \pm 1.96$ & $144.20 \pm 2.10$ & $143.60 \pm 2.27$ \\
\hline $\mathrm{K}^{+}(\mathrm{mEq} / \mathrm{L})$ & $4.34 \pm 0.25$ & $4.39 \pm 0.16$ & $4.37 \pm 0.19$ & $4.21 \pm 0.16$ & $4.27 \pm 0.13$ & $4.32 \pm 0.19$ & $4.29 \pm 0.21$ & $4.25 \pm 0.16$ \\
\hline $\begin{array}{c}\text { Chloride } \\
(\mathrm{mEq} / \mathbf{L}) \\
\end{array}$ & $101.30 \pm 1.16$ & $101.30 \pm 1.16$ & $102.50 \pm 1.90$ & $101.20 \pm 1.87$ & $104.00 \pm 2.31$ & $102.50 \pm 1.18$ & $104.00 \pm 1.33$ & $102.40 \pm 0.70$ \\
\hline $\begin{array}{c}\text { cholinesterase } \\
(\mathrm{U} / \mathrm{L})\end{array}$ & $651.60 \pm 3.24$ & $652.40 \pm 4.30$ & $651.90 \pm 4.07$ & $656.10 \pm 6.72$ & $649.00 \pm 3.50$ & $656.10 \pm 6.72$ & $649.70 \pm 3.20$ & $656.40 \pm 6.87$ \\
\hline
\end{tabular}

Statistical analysis: ANOVA ( $\mathrm{p}$ value $:>0.05$ ), If $\mathrm{p}$ value $<0.05=$ Significant, If $\mathrm{p}$ value $>0.05=$ Non significant

Table.4 Mean biochemistry data of female rats (recovery group)Time: terminal sacrifice (119th day)

\begin{tabular}{|c|c|c|c|c|c|c|c|c|c|c|c|}
\hline $\begin{array}{c}\text { Animal } \\
\text { group }\end{array}$ & $\begin{array}{c}\text { GLU } \\
\text { mg/dl }\end{array}$ & $\begin{array}{c}\text { SGOT } \\
\text { U/L }\end{array}$ & $\begin{array}{c}\text { SGPT } \\
\text { U/L }\end{array}$ & $\begin{array}{l}\text { BUN } \\
\text { mg/dl }\end{array}$ & $\begin{array}{l}\text { UREA } \\
\text { mg/dl }\end{array}$ & $\begin{array}{l}\text { SAP } \\
\text { U/L }\end{array}$ & $\begin{array}{l}\text { T.P } \\
\text { g/dl }\end{array}$ & $\begin{array}{c}\mathrm{Na}^{+} \\
\mathbf{m E q} / \mathbf{L}\end{array}$ & $\begin{array}{c}\text { Potassium } \\
(\mathrm{mEq} / \mathrm{L})\end{array}$ & $\begin{array}{l}\text { Chloride } \\
(\mathrm{mEq} / \mathrm{L})\end{array}$ & $\begin{array}{c}\text { cholinesterase } \\
\text { (U/L) }\end{array}$ \\
\hline $\begin{array}{c}\text { Recovery } \\
\text { control (G-5) }\end{array}$ & $\begin{array}{c}78.80 \\
\pm \\
5.90 \\
\end{array}$ & $\begin{array}{c}84.30 \\
\pm \\
3.33 \\
\end{array}$ & $\begin{array}{c}44.80 \\
\pm \\
3.58 \\
\end{array}$ & $\begin{array}{c}21.58 \\
\pm \\
1.19 \\
\end{array}$ & $\begin{array}{c}45.70 \\
\pm \\
4.47 \\
\end{array}$ & $\begin{array}{c}110.90 \\
\pm \\
7.02 \\
\end{array}$ & $\begin{array}{c}7.76 \\
\pm \\
0.26 \\
\end{array}$ & $\begin{array}{c}144.60 \\
\pm \\
2.46\end{array}$ & $\begin{array}{c}4.16 \\
\pm \\
0.16 \\
\end{array}$ & $\begin{array}{c}102.00 \\
\pm \\
1.15 \\
\end{array}$ & $\begin{array}{c}653.10 \\
\pm \\
5.22 \\
\end{array}$ \\
\hline $\begin{array}{c}\text { Recovery } \\
\text { Intermediater } \\
\text { dose (G-6) }\end{array}$ & $\begin{array}{c}82.90 \\
\pm \\
4.09\end{array}$ & $\begin{array}{c}86.80 \\
\pm \\
7.98\end{array}$ & $\begin{array}{c}47.80 \\
\pm \\
11.67\end{array}$ & $\begin{array}{c}22.33 \\
\pm \\
1.57\end{array}$ & $\begin{array}{l}46.70 \\
\pm \\
4.27\end{array}$ & $\begin{array}{c}112.00 \\
\pm \\
7.09\end{array}$ & $\begin{array}{c}7.79 \\
\pm \\
0.17\end{array}$ & $\begin{array}{c}144.40 \\
\pm \\
1.90\end{array}$ & $\begin{array}{c}4.24 \\
\pm \\
0.20\end{array}$ & $\begin{array}{c}103.00 \\
\pm \\
1.25\end{array}$ & $\begin{array}{c}652.10 \\
\pm \\
3.96\end{array}$ \\
\hline
\end{tabular}


The analysis of biochemical parameters showed that all the parameters of low dose group- (G-2), intermediate dose group (G-3) and high dose group (G-40) were comparable to their control group(G-1), when evaluated on 0 day (pretest), $45^{\text {th }}$ day (interim) of the study and all the parameters of low dose group (G-2) and intermediate dose group (G$3)$ were comparable to their control counterparts, when evaluated on $91^{\text {st }}$ day (terminal sacrifice) of the study. However, a slight increase in SGOT, SGPT were noticed in the intermediate dose group and high dose group animals at terminal sacrifice i.e. day $91^{\text {st }}$ and slight increase in SGOT, SGPT were noticed in the recovery intermediate dose group on terminal sacrifice i.e. $119^{\text {th }}$ day. Reversibility of the toxic effects were seen in recovery intermediate dose animals (G-6) as all the biochemical parameters were comparable to their recovery control counterparts (G-5) as they fell within the accepted laboratory limits.

In conclusion the rat model is a key element in advancing biological research. The prevailing assumption that the responses to exercise obtained from rat models mimic human responses to exercise is supported by our study at least regarding most of the blood parameters measured. Rat demonstrated adequately reflected human responses to repeated exercise in blood parameters linked to various organs, tissues, functions, and diseases. Although it is plausible to anticipate similar blood profile changes in humans and rats after multiple exercise sessions. It is vital that future research directly compares rat and human responses to acute and chronic exercise in additional variables and sampling points. Our study highlights the various change in biochemimal parameters of female wistar rats over repeated exposure by Fomesafen by oral route through gavage. Under the conditions of this study, the repeated oral administration of 'Fomesafen technical' in Female wistar rats at the dosage level of $50 \mathrm{mg} / \mathrm{kg}$ b.wt. for consecutive 90 days did not induce any observable toxic effects, alteration in blood biochemistry parameters when compared to its corresponding control group of animals.

\section{References}

Chauhan, A. and Goyal, P. 2013. Isolation and Identification of Escherichia coli from various foodstuffs and their resistance against clinically significant antibiotics, J. Adv. Biol., 2: 45-53.

Chauhan, A., Goyal, P., Aggarwal, M.L., and Chacko, K.M. 2013. Prevalence and antibiotic resistance of Bacillus strains isolated from various food stuffs. $J$. Biomed. Pharmaceutical Res., 2(3): 0816.

Chauhan, A., Goyal, P., Verma, A and Jindal, T. 2015. Microbiological evaluation of drinking water sold by roadside vendors of Delhi, India. Appl. Water Sci., DOI 10.1007/s13201-015-0315-x.

Muthamia, J.G.N., Musembi, F., Maina, J.M., Okuro, J.O., Amboga, S. and Muriithi, F. 2001. Participatory on-farm trials on weed control in smallholder farms in maize-based cropping systems. Proc. $7^{\text {th }}$ Eastern and South Africa Regional Maize Conf., Nairobi, Kenya, pp. 46873.

Ortiz-Monasterio, I., Wassmann, R., Govaerts, B., Hosen, Y., Katayanagi, N. and Verhulst, N. 2010. Greenhouse gas mitigation in the main cereal systems: rice, wheat and maize, in Climate Change and Crop Production. CABI, Wallingford, Oxon, UK.

Overfield, D., Murithi, F.M., Muthamia, J.N., Ouma, J.O., Birungi, K.F. and Maina J.M. 2001. Analysis of the constraints to adoption of herbicides by smallholder maize growers in Kenya and Uganda. Proc. Brighton Crop Protection Conf.- 
Weeds, BCPC, Farnham, Surrey, UK, pp. 907-912.

Paller, E.C., Ramirez, A.H.M. and Malenab, E.T. 2001. Weed management in grain corn: comparing calendared treatments and use of weed control action indicators (WCAI). Philipp. J. Crop Sci., 27(1): 9-12.

Penna, J.A. and Lema, D. 2003. Adoption of herbicide tolerant soybeans in Argentina: an economic analysis, in Economic and Environmental Impacts of Agrotechnology. Kluwer-Plenum, New York, NY, pp.203-220.

Pereira, P.A.A., Martha, G.B., Jr, Santana, C.A.M. and Alves, E. 2012. The development of Brazilian agriculture: future technological challenges and opportunities. Agric Food Security, 1: 4.

Philips McDougall. 2013. [Online]. Available: http://phillipsmcdougall.co

Pingali, P.L. and Gerpacio, R.V. 1997. Towards reduced pesticide use for cereal crops in Asia. CIMMYT Working Paper, 97-04.

Prasad, A., Singh, G. and Upadhyay, R.K. 2008. Integrated weed management in maize (Zeamays L.) and maize + blackgram. Indian J. Weed Sci., 40(3/4): 191-192.

Prateher, T.S. Ditomaso, J.M. and Halt, J.S. 2000. Herbicide resistance: Definition and Management. Available at: http://anrcatalog.ucdavis.edu/

Pretty, J. and Hine, R. 2001. Portraits of Sustainable Agriculture Projects and Initiatives. Centre for Environment and Society, University of Essex.

Rashid, M.H., Alam, M.M. and Ladha, J.K. 2012. Comparative efficacy of pretilachlor and hand weeding in managing weeds and improving the productivity and net income of wetseeded rice in Bangladesh. Field Crops Res., 128: 17-26.

Ribeiro, M.F.S., Denardin, J.E., Bianchini, A.,
Ferreira, R., Flores, C.A. and Kliemann, H.J. 2007. Conservation Agriculture Research in Brazil. Deliverable 1.4Appendix A1.[Online].KASSA (2007). Available at: http://kassa.cirad.fr /

Riley, H. 2006. Long-term tillage trials on loam and clay soils in SE Norway: yield results for 1998-2004. Nordic Association of Agricultural Scientists. NJF Seminar, 3782(4): 190-195.

Rodenburg, J. and Demont, M. 2009. Potential of herbicide resistant rice technologies for sub-Saharan Africa. Ag. Bio-Forum, 12(3/4): 313-325.

Salonen, J., Hyvonen, T., Kaseva, J. and Jalli, H. 2012.Impact of changed cropping practices on weed occurrence in spring cereals in Finland- a comparison of surveys in 1997-1999 and 2007-2009. Weed Res., 53: 110-120.

Savary, S., Willocquet, L., Elazegui, F.A., Castilla, N.P. and Teng, P.S. 2000. Rice pest constraints in tropical Asia: quantification of yield losses due to rice pests in a range of production situations. Plant Dis., 84: 357-369.

Schroder, D., Headley, J.C. and Finley, R.M. 1984. The contribution of herbicides and other technologies to corn production in the corn belt region 19641979. N Cent J. Agric. Econ., pp

Shad, R.A., Chatha, M.Q. and Nawaz, H. 1993. Weed management studies in maize. Pak. J. Agric. Res., 14(1): 4450.

Sohail, A., Mahmood, J., Khan, M.H. and Mahmood, M.M. 1993. Evaluation of some insecticides on maize against Chilopartellus (Swinhoe). Pak J. Agric. Res., 14(4): 393-395.

Takeshita, T. and Noritake, K. 2001. Development and promotion of labor saving application technology for paddy herbicides in Japan. Weed Biol. Manag., 1: 61-70.

Tareen, M.A.K., Chatha, M.Q., Malik, H.N. 
and Javed, H.I. 1991. Effect of Primextra herbicide on the productivity of maize grown under medium rain fed conditions. Pak. J. Agric. Res., 12(4): 257-263.

Wang, I.K. 1971. Diffusion and acceptance of recommended farm practices for increased food production. College of Agriculture, Seoul National University, Seoul, South Korea.

WAP (World Agricultural Pesticides). 2014. Industry market research for business leaders, strategists, decision makers. Pp. 399-411

Wylie, P. 2008. High profit farming in Northern Australia. Grains Research and Development Corporation, Barton, ACT, Australia.

Zakharenko, V.A. 2000. Bio-economic methods and decision-making models for herbicide use in Russian agriculture. $3^{\text {rd }}$ Int. Weed Science Congr., Foz do Iguaçu, Paraná, Brazil.

Zakharenko, V.A. 2004. Phytosanitary condition of agro-ecosystems and potential yield losses from harmful organisms in agriculture under conditions of Russia's multiform economy. Russ. Agric. Sci., 5: 13-18.

Zhang, C.X., Liu, Y., Cui, H.L., Wei, S.H. and Huang, H.J. 2007. Herbicide usage and associated problems in China. XVI Int. Plant Protection Congr., Glasgow, UK.

Zhang, Z.P. 2003. Development of chemical weed control and integrated weed management in China. Weed Biol. Manag., 3: 197-203.

\section{How to cite this article:}

Alok Paliwal, M.L. Agarwal, K.M. Chacko, Anurag Singh, Abhishek Chauhan and Tanu Jindal. 2017. Physiological and Biochemical Evaluation of Fomesafen Toxicity in Female Albino Wistar Rats. Int.J.Curr.Microbiol.App.Sci. 6(4): 116-124. doi: https://doi.org/10.20546/ijcmas.2017.604.014 